\title{
ZBTB33 wt Allele
}

National Cancer Institute

\section{Source}

National Cancer Institute. ZBTB33 wt Allele. NCI Thesaurus. Code C155730.

Human ZBTB33 wild-type allele is located in the vicinity of Xq24 and is approximately $8 \mathrm{~kb}$ in length. This allele, which encodes transcriptional regulator Kaiso protein, is involved in transcriptional regulation, signaling and DNA binding. 